\title{
New records of the genus Eilicrinia Hübner, 1823 (Lepidoptera: Geometridae) in Croatia
}

\author{
Novi nalazi roda Eilicrinia Hübner, 1823 (Lepidoptera: Geometridae) \\ u Hrvatskoj
}

Toni Koren*

Association Hyla, Lipovac I, n. 7, 10000 Zagreb, Croatia

*Corresponding author E-mail address: koren.toni1@gmail.com (T. Koren)

\begin{abstract}
New records of the genus Eilicrinia Hübner, 1823 in Croatia are presented and the previous literature records are summarized. Eilicrinia cordiaria (Hübner 1790) has been recorded in Croatia after an apparent absence of 36 years at six new localities. The species has a scattered distribution in the country, with historical records originating from both Mediterranean and Continental regions while recent reports are limited to northern Croatia, mostly around the rivers Drava and Mura. For Eilicrinia trinotata (Metzner 1845) the first record from Croatia is presented, from Bansko hill in Baranja region. Both species can be considered as scarce in Croatia and further studies are needed in order to assess their status and distribution.
\end{abstract}

Keywords: Moths, diversity, distribution

\section{Sažetak}

Predstavljeni su novi nalazi roda Eilicrinia u Hrvatskoj, a dosadašnji literaturni su sažeti. Eilicrinia cordiaria (Hübner 1790) zabilježena je na području Hrvatske nakon 36 godina na šest novih lokacija. Vrsta ima raspršenu rasprostranjenost $\mathrm{u}$ zemlji, $\mathrm{s}$ povijesnim nalazima koji potječu iz mediteranskih i kontinentalnih područja, dok su noviji ograničeni na sjevernu Hrvatsku, uglavnom okolicu rijeka Drave i Mure. Vrsta Eilicrinia trinotata (Metzner 1845) po prvi je puta zabilježena u fauni Hrvatske sa područja Banskog brda u Baranji. Čini se da su obje vrste lokalne u Hrvatskoj te su potrebna daljnja istraživanja kako bi se procijenio njihov status i rasprostranjenost.

Ključne riječi: noćni leptiri, raznolikost, rasprostranjenost

\section{Introduction}

The genus Eilicrinia Hübner, 1823 belongs to the Enomiinae subfamily of the Geometridae and contains eleven described species, predominately distributed in the Palearctic and Oriental regions (Skou and Sihvonen 2015). They are medium sized moths with a wingspan of about $30 \mathrm{~mm}$ and with the forewing concaved below the apex. In Europe three species are present, all of which are easily recognizable: Eilicrinia trinotata (Metzner, 1845), Eilicrinia cordiaria (Hübner 1790) and Eilicrinia subcordiaria Herrich-Schäffer, 1852 (Skou and Sihvonen 2015). In Croatia, only Eilicrinia cordiaria was known prior to the present results with the most recent records being from the 1985 (Kranjčev 1985; Mihoci 2012); this species was not recorded in Croatia in the more recent moth surveys of Vignjević et al. (2010), Koren and Gomboc (2017) and Koren (2018).

The aim of this paper is to present new records of the genus Eilicrinia in Croatia with some notes about their habitats and distribution. 


\section{Materials and methods}

Lepidoptera material has been collected in Croatia by the author for the last ten years, and Geometridae were collected along with other Lepidoptera families using pyramidal UV light traps. Usually, five traps were in operation for about 4 h after dusk at each locality. All the data for the visited localities is provided in the next chapter for each recorded species. The collected specimens were set, identified and stored in the private collection of the author. For the identification of species Skou and Shivonen (2015) was used.

\section{Results}

Two species of genus Eilicrinia have been recorded in Croatia and their distribution is given in Fig. 1.

Eilicrinia cordiaria (Hübner 1790)

Literature records: Slavonia (Bohatsch 1892), Rijeka (Fiume), Lipik (Abafy-Aigner et al. 1896), Bakar (Buccari), Middle Dalmatia (Mittledalmatien) (Stauder 1929), Đelekovec, Sigetec (Kranjčev 1985).

New records: Croatia, Međimurska County, south of Donja Dubrava, forest near Drava river, 46,309399 ${ }^{\circ} \mathrm{N}, 16,788258^{\circ} \mathrm{E}, 179$ m, 9.6.2021, 5 ex., 15.7.2021, 1 ex; Croatia, Podravina, Križnica, western part, flooded forest near Drava river, $45,973849^{\circ} \mathrm{N}$, 17,339984 E, 105 m, 24.7.2019, 2 ex.; Croatia, Podravina, Križnica, old bayou of Drava river, reeds and forest edge, 45,962317 ${ }^{\circ} \mathrm{N}, 17,359826^{\circ} \mathrm{E}, 108 \mathrm{~m}, 24.7 .2019,4$ ex.; Croatia, Nature Park Kopački Rit, Kopačevo, forest close to Biljsko jezero, 45,59407 N, 18,78325 E, 80 m, 2.vi.2021, 4 ex.; 22.6.2021, 1 ex.; Croatia, Nature Park Kopački Rit, Ćošak šume, edge of wetland forest near the Vardarac canal, 45,639047 ${ }^{\circ} \mathrm{N}, 18,850989^{\circ}$ E, 157 m, 4.6.2021; Croatia, Baranja, Bansko Brdo south of Branjina, dry pastures partially overgrown in bushes, 45,812769 ${ }^{\circ} \mathrm{N}, 18,694468^{\circ} \mathrm{E}, 144 \mathrm{~m}, 3.6 .2021,2 \mathrm{ex}$.

Eilicrinia trinotata (Metzner 1845)

New records: Croatia, Baranja, Bansko Brdo south of Branjina, dry pastures partially overgrown in bushes, $45,812769^{\circ} \mathrm{N}, 18,694468^{\circ} \mathrm{E}, 144 \mathrm{~m}, 3.6 .2021,1$ ex.

\section{Discussion}

Of the two species present in Croatia, Eilicrinia cordiaria (Fig. 2a) is the most widely distributed European species, occurring from eastern Austria and Slovakia, across Hungary, the Balkans and the Ukraine as far as the southern Urals (Skou and Sihvonen 2015).

New records are located in the northern Croatia, along rivers Drava and Mura (Fig. 1). Most of the habitats where the species was recorded were floodplain forests in which its hostplants, Salix spp. grow in abundance (Fig. 2c). This is also in accordance with the recent observations from Belarus (Kulak 2017). The only exception is Bansko Brdo, which is a loess hilly plateau with its highest summit of $251 \mathrm{~m}$, located in Baranja county. No Salix spp. have been observed in this area, but just below the hill, willow trees are present along the small stream. This may explain its occurrence in the area. In respect of historical records, those from the Mediterranean region have not been confirmed; records from Bakar and from Dalmatia were given without any specific 
locality (Stauder 1929). During the last ten years the author has visited many localities across whole Croatia, including the coastal areas of Dalmatia, but this species has not been recorded. However, it is possible that the species still survives in some areas of Kvarner and Dalmatia as many areas still remain to be explored in more detail. Especially the area of mainland Kvarner since it has not been surveyed after the work of (Stauder 1929), so new surveys in that area are needed. With the records presented in this work the occurrence in Croatia has been significantly increased, but it is still probable that the species has a wider distribution and additional surveys are needed across the country in order to confirm this. The records from Croatia expand the known areal only slightly, and concur with the distribution pattern presented in Skou and Shivonen (2015).

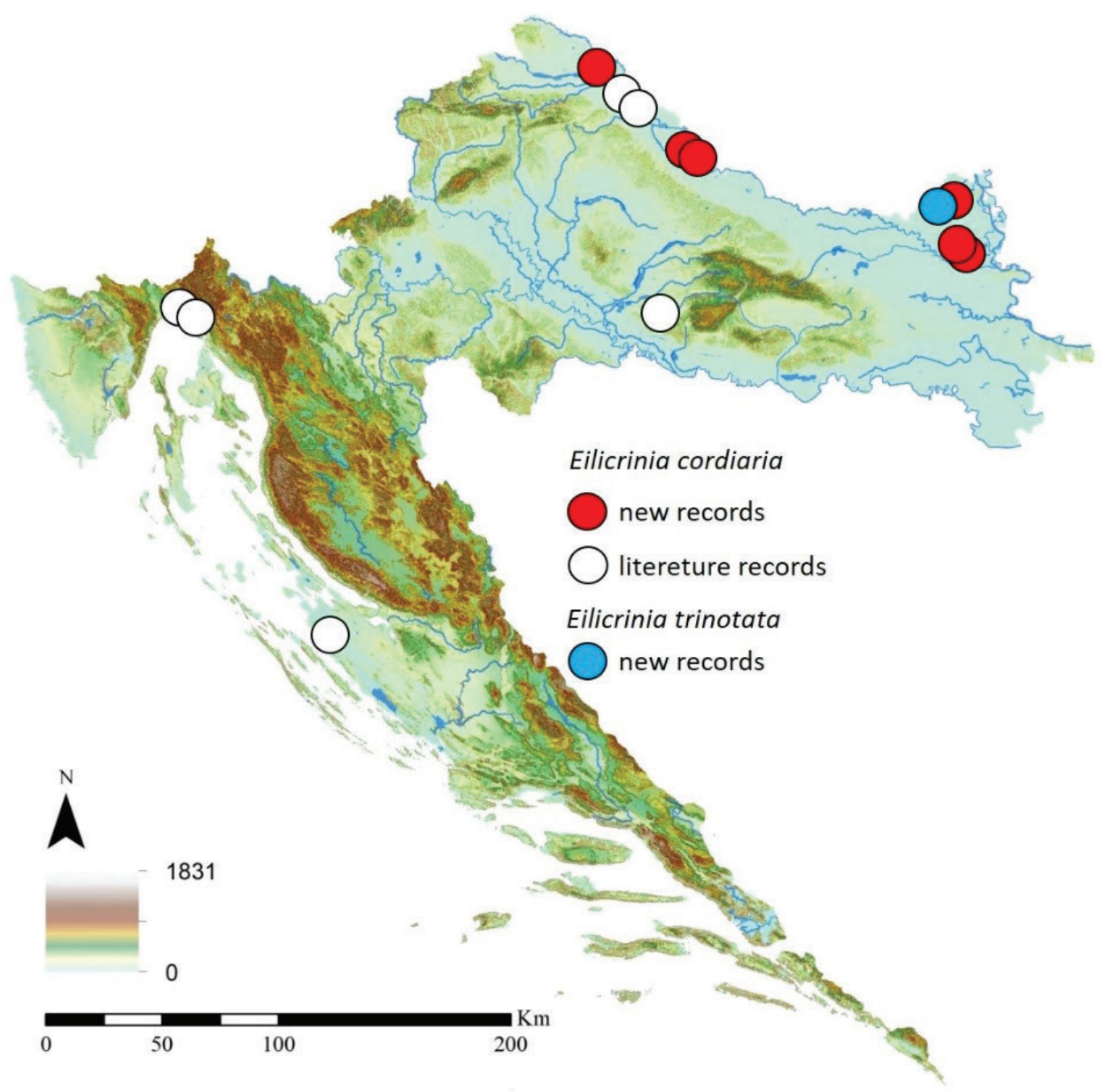

Figure. 1. Distribution of the genus Eilicrinia in Croatia. 

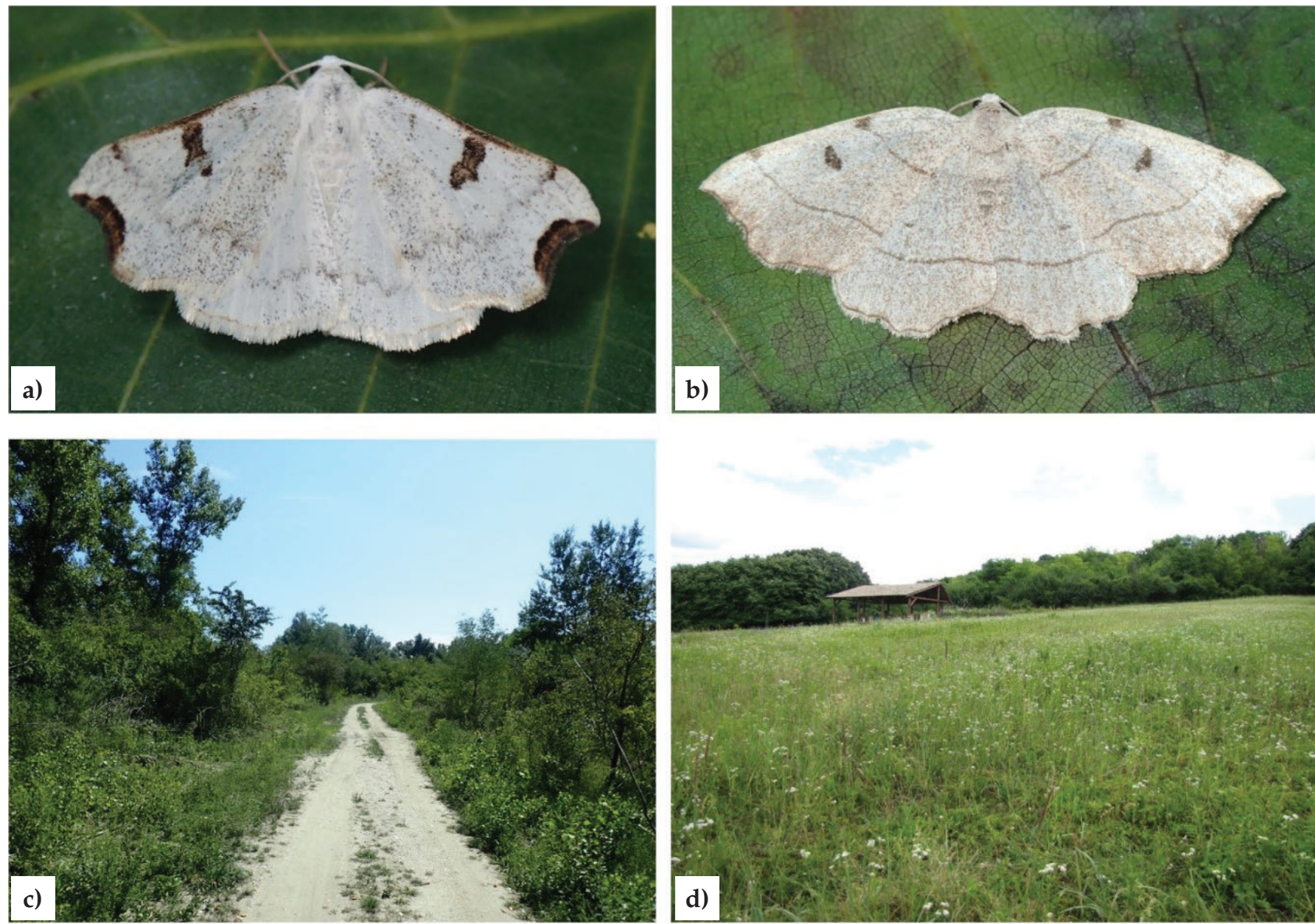

Figure 2. a) Eilicrinia cordiaria from Kopački rit, Croatia, b) habitat of E. cordiaria SW of Donja Dubrava, near river Drava, c) Eilicrinia trinotata from Bansko brdo, Baranja, d) Habitat of E. trinotata at Bansko brdo, Baranja.

The other species present in Croatia, E. trinotata (Fig. 2b) has a much smaller area of occurrence in Europe. It is present from Hungary and Slovakia and then towards the south-east across the Balkans as well as east to the Ukraine and parts of Russia (Skou and Sihvonen 2015).

While the general distribution of the species along the Hungarian and Serbian borders indicates its likely presence in Croatia, it has not been recorded (Mihoci 2012). Accordingly, it can now be regarded as a new member of the fauna of Croatia.

So far, a single specimen was collected in Croatia, in the area of Bansko brdo (Fig. 2d). The locality is dominated by partially overgrown, dry grasslands which are still being used for sheep grazing. However, in the last ten years a large portion of the former grassland has been converted into an orchard, rending the grassland even smaller (authors personal observations). According to Skou and Shivonen (2015) E. trinotata occurs in steppe and forest steppe localities, which is in accordance with the locality on Bansko brdo in Baranja. The area of Bansko brdo is significant for the both floristic and faunistic diversity Croatia, with several new species for the country recorded there (e.g. Purger and Csiky 2008; Uherkovich et al. 2008; Csiky and Purger 2013). This record supports the importance of this site. This species usually has two generations with a partial third also being observed (Ziegler 2016). The caterpillars have been bred on Ulmus glabra and Ulmus minor (Ziegler 2016). 
Baranja in general is one of the least studied parts of Croatia, with only exception being Nature park Kopački Rit where recently 201 moth species have been recorded (Vignjević et al. 2010). Other than that, the area of Baranja remains poorly surveyed and additional localities for this and other interesting species are to be expected in the future. As the human influence in the area is very strong, not much of the natural or even seminatural habitats remain in the area. The butterfly fauna of Bansko brdo is rather diverse for the area (Koren et al. 2012) so it is probable the same will be true also for moth fauna. In order to gain an insight into the remaining moth diversity in the area a study of the remaining habitats with steppe elements should be done in the near future.

\section{References}

Abafy-Aigner, L., Pável, J., Uhryk, F. 1896. Fauna Regni Hungariae. Ordo Lepidoptera. Regia Societas Scientiarum Naturalium Hungarica. 3: 1-82.

Bohatsch, O. 1892. Beiträge zur Lepidopteren-Fauna Slavoniens. Wiener Entomologischen Vereines. 31-50.

Csiky, J., Purger, D. 2013. Herbaceous periwinkle,Vinca herbacea Waldst. et Kit. 1799 (Apocynaceae), a new species of the Croatian flora. Acta Botanica Croatica. 72 (2): 399-406.

Koren, T. 2018. Diversity of moths (Lepidoptera: Heterocera) in the surroundings of the Bednja River, Varaždin County, Northern Croatia. Natura Croatica. 18: 111-141.

Koren, T., Gomboc, S. 2017. Noćni leptiri Krapinsko-zagorske županije. Javna ustanova Za upravljanje zaštićenim dijelovima prirode Krapinsko-zagorske županije, Zagreb.

Koren, T., Krčmar, S., Dretvić, T. 2012. Contribution to the knowledge of butterflies (Lepidoptera: Rhopalocera) of Bansko brdo. Entomologia Croatica. 16: 41-60.

Kranjčev, R. 1985. Odnos faune makrolepidoptera prema prirodnim i antropogenim staništima Podravine i podravskih pijesaka (I). Podravski zbornik. 11: 200-226.

Kulak, A.V. 2017. European area dynamics of Eilicrinia cordiaria cordiaria (Hübner, [1790]) (Lepidoptera: Geometridae, Ennominae) under the present climate change. Nachrichten des Entomologischer Verein Apollo. 38: 212-216.

Mihoci, I. 2012. Raznolikost grbica (Lepidoptera, Geometridae) Hrvatske i ekološka uvjetovanost njihove visinske rasprostranjenosti (PhD). University of Zagreb, Faculty of Science, Zagreb.

Purger, D., Csiky, J. 2008. Dwarf iris, Iris pumila L. (Iridaceae), a new species of the Croatian flora. Acta Botanica Croatica. 67 (1): 97-102.

Skou, P., Sihvonen, P. 2015. Ennominae I., The Geometrid Moths of Europe. Brill, Leiden.

Stauder, H. 1929. Die Schmetterlingsfauna der illyro-adriatischen Festland- und Inselzone (Faunula Illyro-Adriatica). Entomologischen Anzeiger 9, 39-41, 53-58, 65-72, 88-94, 115-117, 131-137, 157-158, 177-178, 194-199, 213-218, 233-236, 251-252, 272-273, 292-293, 299-306, 318-325, 359-364, 379-384, 397-403, 420-423, 437-442.

Uherkovich, Á., Purger, D., Csiky, J. 2008. First find Of Pomatias rivularis (Eichwald, 1829) (Mollusca: Pomatiidae) in Croatia. Natura Croatica. 17 (3): 183-192.

Vignjević, G., Zahirović, Ž., Turić, N., Merdić, E., 2010. Moths (Lepidoptera: Heterocera) of Kopački rit Nature Park - Results of preliminary research. Entomologia Croatica. 14: 17-32.

Ziegler, H., 2016. Beitrag zur Kenntnis der Biologie von Eilicrinia trinotata (Metzner, 1845) sowie Wertung eines alten Einzelfundes dieser Art im Südtessin. Atalanta. 47: 255-257. 